\title{
THE MAGNESIUM STATUS OF SOIL AND THE MAGNESIUM CONTENT OF CULTIVATED PLANTS
}

\author{
RAILI JOKINEN \\ University of Helsinki, Department of Agricultural Chemistry, Viik \\ Department of Agricultural Chemistry and Physics, Agricultural Research Centre, Tikkurila
}

Received October 16,1969

The general adoption of high-percentage fertilizers directs attention to such nutrients as magnesium - all the more so because magnesium is also important to animals. In many instances, the use of magnesium fertilizer has led to only slight yield increases, whereas the magnesium content of plants has risen. According to Salmon (1964), the content of exchangeable magnesium in the soil would have to increase fourfold in order to double the magnesium content of the plants.

ITALLIE (1937) observed that the magnesium content of plants is influenced to a greater extent by the ratio of the magnesium to the other cations present in the soil than by the amount of exchangeable magnesium.

The aim of the present paper is to study the influence of the magnesium saturation percentage and the ratio of exchangeable potassium and magnesium in the soil on the magnesium content of potato leaves, red clover and timothy yields.

\section{Material}

The material of the study was collected in 1966 and 1967 from cultivated fields in the regions of Satakunta and Etelä-Pohjanmaa (= South Bothnia). The total yield of red clover-timothy leys of a sampling area measuring $0.25 \mathrm{sq}$. $\mathrm{m}$ on each of a total of 90 farms was collected. The quantity and the botanical composition of the hay samples was determined. One of the hay samples contained no timothy and 18 of them no clover. In addition to 72 clover and 89 timothy samples, the material contained samples of potato plants (three or four undermost leaves) taken from 115 different sites (each plot measuring $1 \mathrm{sq}$. $\mathrm{m})$. In the taking of the samples, no signs of a magnesium deficiency could be detected in the plants. The clover and timothy material had been investigated previously by the 
author (JoKINEN 1969) in a study of the influence of the clover content of mixed leys on the amount of magnesium present in red clover and timothy as well as on the cation ratios.

A sample of the soil was further taken from the top soil layer $(0-20 \mathrm{~cm})$ at each investigated site.

From the plant samples the content of total magnesium was determined, $\mathrm{mg} / \mathrm{g}$ dry matter; and from the soil samples the $\mathrm{pH}\left(0.01 \mathrm{M} \mathrm{CaCl}_{2}\right)$, the per cent of the clay fraction $(<2 \mu)$ and the organic carbon, the cation exchange capacity me/100 g, the content of exchangeable magnesium $\mathrm{mg} / 100 \mathrm{~g}$, the magnesium saturation per cent, and the ratio of the exchangeable potassium to the magnesium on an equivalent basis. The methods applied in the analyses are described in the report cited (JokINEN 1969, pp. 3-4).

\section{Results and discussion}

The average magnesium contents of the plant samples and the clover and timothy yields obtained from the sampling plots are presented in Table 1. The contents obtained for the clover and the timothy are nearly the same as those reported by other Finnish research workers (e.g., KerÄnen and Tainio 1968, LAKAnEN 1969). The variation in the magnesium contents of the potato leaves exceeds that in the results obtained by HoffmanN (1962).

Table 1. The magnesium contents of plant samples (mg/g dry matter) and the yields ( $\mathrm{g} / 0.25 \mathrm{sq} \cdot \mathrm{m})$.

\begin{tabular}{|c|c|c|c|c|}
\hline & $\begin{array}{c}\text { No. of } \\
\text { samples }\end{array}$ & & $\begin{array}{c}\mathrm{Mg} \\
\mathrm{mg} / \mathrm{g}\end{array}$ & $\begin{array}{c}\text { Yield } \\
\mathrm{g} / 0.25 \text { sq.m }\end{array}$ \\
\hline Clover & 72 & $\begin{array}{l}\text { a mean } \\
\text { b range } \\
c \text { coeff. of variat. }\end{array}$ & $\begin{array}{c}3.9 \pm 0.3 \\
1.9-8.6 \\
0.31\end{array}$ & $\begin{array}{c}29 \pm 6.7 \\
0.2-121\end{array}$ \\
\hline Timothy & 89 & $\begin{array}{l}\mathrm{a} \\
\mathrm{b} \\
\mathrm{c}\end{array}$ & $\begin{array}{c}1.2 \pm 0.1 \\
0.6-1.9 \\
0.25\end{array}$ & $\begin{array}{r}83 \pm 9.1 \\
2-181\end{array}$ \\
\hline Potato & 115 & $\begin{array}{l}\mathrm{a} \\
\mathrm{b} \\
\mathrm{c}\end{array}$ & $\begin{array}{l}8.1 \pm 0.6 \\
2.0-18.8 \\
0.28\end{array}$ & \\
\hline
\end{tabular}

The results of the soil analyses from leys and potato fields are presented separately in Table 2. They reveal a wide range of variation, but the values are typical of soils in Finland.

In the light of the present material, the age of a ley (one to five years) did not make any statistically significant difference to the magnesium content of the clover or timothy samples. In the field tests carried out by Salonen and Hirvola (1963), the magnesium content of clover, in particular, was in inverse ratio to the age of the ley. The variation in the results may be due to the fact that the material of this study was collected from 90 different farms and does not represent the variation occurring in the plant stands growing in the same place. 
Table 2. Properties of soils under leys and potato.

\begin{tabular}{|c|c|c|c|}
\hline & & Leys & Potato fields \\
\hline \multirow[t]{2}{*}{$\mathrm{pH}\left(\mathrm{CaCl}_{2}\right)$} & a mean & $5.0 \pm 0.14$ & $5.1 \pm 0.09$ \\
\hline & b range & $3.7-6.6$ & $4.2-6.7$ \\
\hline \multirow[t]{2}{*}{ Clay fraction $(<2 \mu)$} & a & $26 \pm 2.7$ & $22 \pm 3.1$ \\
\hline & b & $7-61$ & $3-64$ \\
\hline \multirow[t]{2}{*}{ Org. C \% } & a & $4.5 \pm 0.49$ & $4.3 \pm 0.45$ \\
\hline & b & $1.3-20.0$ & $1.5-14.1$ \\
\hline \multirow[t]{2}{*}{ CEC $\mathrm{me} / 100 \mathrm{~g}$} & a & $21.3 \pm 1.82$ & $20.7 \pm 1.33$ \\
\hline & b & $9.2-66.9$ & $9.0-46.9$ \\
\hline \multirow[t]{2}{*}{$\mathrm{Mg} \mathrm{mg} / 100 \mathrm{~g}$} & a & $21.9 \pm 3.89$ & $21.9 \pm 3.04$ \\
\hline & $\mathbf{b}$ & $1.8-95.0$ & $1.3-79.0$ \\
\hline \multirow[t]{2}{*}{ Mg-saturation \% } & a & $8.5 \pm 1.35$ & $8.3 \pm 0.86$ \\
\hline & $\mathbf{b}$ & $1-30$ & $1-22$ \\
\hline \multirow[t]{2}{*}{ K-saturation \% } & a & $1.8 \pm 0.22$ & $3.3 \pm 0.35$ \\
\hline & b & $0.3-6$ & $1.0-9$ \\
\hline \multirow[t]{2}{*}{$\mathrm{K} / \mathrm{Mg}$} & a & $0.29 \pm 0.07$ & $0.57 \pm 0.11$ \\
\hline & b & $0.02-3.03$ & $0.05-3.49$ \\
\hline
\end{tabular}

The correlation between the rate of yield and the magnesium content of the plants (timothy $\mathrm{r}=0.089$, clover $\mathrm{r}=-0.053$ ) was not significant either. According to the results collected from field tests carried out during the years 1928 - 1960, the magnesium content of the timothy yield rose significantly with the increase in the yield per hectare, when the leys were fertilized nearly identically (HeINONEN 1964).

The soil samples investigated divided into the different classes as follows:

$$
\begin{aligned}
& \text { No. of samples } \\
& \text { Leys } \quad \text { Potato fields }
\end{aligned}
$$

$\begin{array}{lll}\text { Fine sand } & 25 & 49 \\ \text { Loam and silt } & 22 & 28 \\ \text { Clay } & 32 & 32\end{array}$

In the group of muddy clays (5 hay samples and 1 sample of leaves from potato plants) and humus soils ( 6 hay samples and 5 potato leaf samples), the number of samples was so small that it was deemed inadequate to give a reliable picture in a comparison between different types of soil. The magnesium content of the timothy and clover samples obtained from the three other soil groups showed no significant variance. The magnesium content of the potato leaves representing fine-sand soils, on the other hand, was significantly lower than that of the samples representing other types of soil. According to the studies of KAILA and Rytr (1968), the fine-sand fraction of Finnish soils contains only one-fourteenth of 
the exchangeable magnesium of a clay fraction. In the present material, the small amount of exchangeable magnesium in fine-sand soils was reflected only in the low magnesium content of potato leaves.

The regression lines between the part of the cation exchange capacity taken up by the magnesium (magnesium saturation percentage, $x_{2}$ ) and the magnesium content of potato leaves, clover and timothy yield $\left(\mathbf{x}_{1}\right)$ are presented in Fig. 1. The figure shows that the magnesium content of plants increases with a rise in the magnesium saturation percentage in the soil. As far as clover is concerned, the effect is not, however, statistically significant. In the light of the present material, the said property of the soil explains $48 \%$ of the total variation in the magnesium content of the potato leaves, $23 \%$ of the timothy samples and $5 \%$ of the clover samples. Among others Rerth (1963) and Semb (1964) have described the magnesium content of clover as being more clearly dependent on the amount of exchangeable magnesium in the soil than that of timothy. The results of the present study are in disagreement with the reports cited.

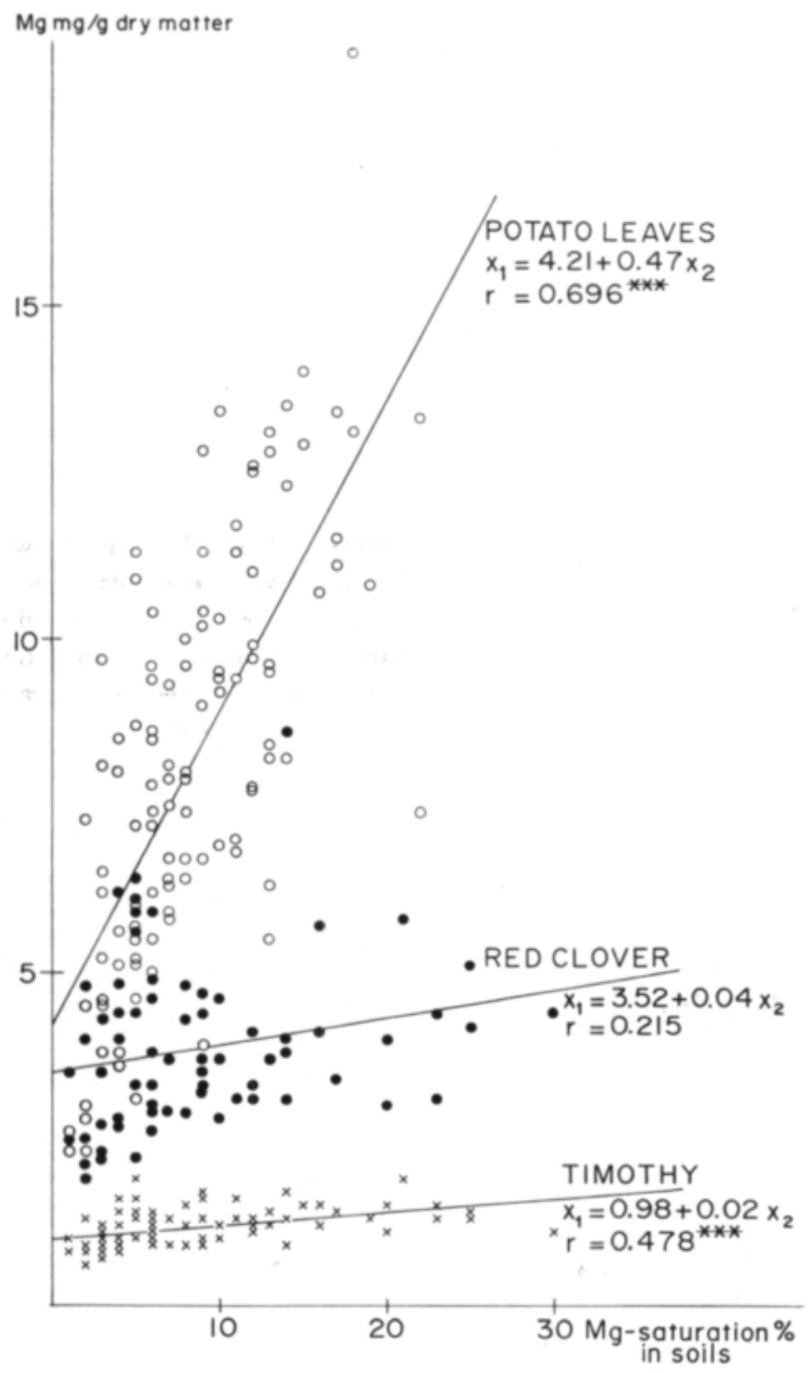

Figure 1. Regression lines between the magnesium contents of potato leaves, clover and timothy and the magnesium saturation percentage in the soil. 
The correlations between the content of exchangeable magnesium in the soil $(\mathrm{mg} / 100 \mathrm{~g}$ of soil) and the magnesium content of the plants were as follows: potato $\mathrm{r}=0.558 * * *$, timothy $\mathrm{r}=0.431^{* * *}$ and clover $\mathrm{r}=0.187$. In comparing these coefficients to those in Fig. 1, it will be noted that in the present material the variations in the magnesium contents of plants are more fully reflected by the magnesium saturation percentage of the soil than by the absolute amount of the element present. This may be considered an indication of the importance of the relative magnesium content of soil.

Although the magnesium content of the soil (mg/100 g) has not affected the corresponding content of clover, a significant correlation does exist between the magnesium content of the soil and the clover yield obtained from the area of the sampling plot $\left(r=0.436^{* * *}\right)$. The quantity of the timothy yield did not depend on the magnesium content of the soil $(\mathrm{r}=0.011)$, but increasing availability of soil magnesium to plants appears to improve the quality of the timothy yield in particular.

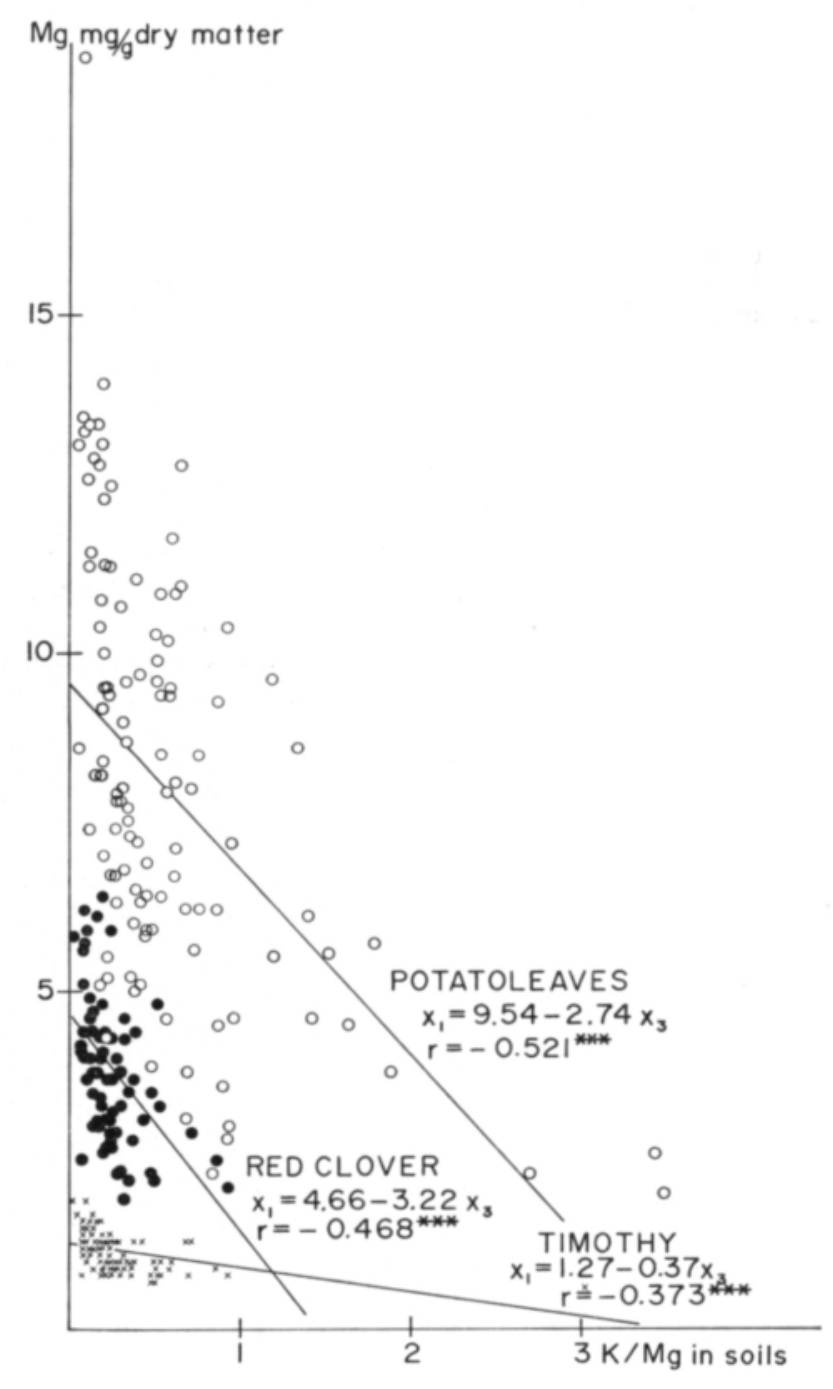

Figure 2. Regression lines between the magnesium contents of potato leaves, clover and timothy and the ratio of exchangeable potassium and magnesium on the equivalent basis in the soil. 
The high magnesium content of the potato leaves $(8.6 \mathrm{mg} / \mathrm{g} \mathrm{d} . \mathrm{m}$.) and its exceedingly significant dependence on the magnesium saturation percentage in the soil indicate that the potato needs magnesium in abundance. According to Hofrmann (1962), six different properties of the soil explain only about $40 \%$ of the total variations in the magnesium content of the three undermost leaves of a potato plant. The part of the magnesium available to plants accounts for $25 \%$ in itself. Growth disturbances accompanied by deficiency symptoms probably affect the potato yield also.

With respect to the relationships existing in the soil between magnesium and other cations, in the present investigation special attention was paid to the effect of the ratios of exchangeable potassium and magnesium (on an equivalent basis, $\mathbf{x}_{3}$ ) on the magnesium content of plants $\left(\mathbf{x}_{1}\right)$. The results obtained are presented in Fig. 2 as regression lines between variables. According to the coefficients of correlation, the magnesium content of all the plants decreased very significantly in the statistical sense as the value of the $\mathrm{K} / \mathrm{Mg}$ ratio in the soil increased. This property of the soil alone explained $22 \%$ of the total variations in the magnesium content of clover, i.e., substantially more than did the magnesium saturation percentage. As for the variations in the magnesium content of potato leaves and timothy, only $27 \%$ and $14 \%$, respectively, could be explained in the light of the present material as dependent on the $\mathrm{K} / \mathrm{Mg}$ value of the soil. A distinct negative correlation has been reported, for example, by Lengauer and Schilling (1964) as well as Hooper (1967). On the basis of the results, one might assume the antagonism between the potassium and the magnesium to appear only in the soil and to influence indirectly the magnesium content of plants (cf., Holmes 1962).

The following coefficients of determination and multiple determination reveal the part of the variations in the magnesium content of plants $\left(\mathbf{x}_{1}\right)$ wich are explained by the saturation percentage of the magnesium in the soil $\left(\mathrm{x}_{2}\right)$ and the ratio $\mathrm{K} / \mathrm{Mg}\left(\mathrm{x}_{3}\right)$ together:

$\begin{array}{lcc} & \mathrm{r}_{12}^{2} & \mathrm{R}_{1 \cdot 23}^{2} \\ \text { Clover } & 0.05 & 0.34 \\ \text { Timothy } & 0.23 & 0.34 \\ \text { Potato } & 0.48 & 0.51\end{array}$

Thus $34 \%$ of the variations in the magnesium content of the clover and timothy yields and $51 \%$ of those of potato leaves could be attributed to the two soil properties in question. SEMB (1964) reports that with respect to clover and timothy, the explanation percentage might rise as high as 50 to 75 .

The negative influence on the magnesium content of plants exerted by a rise in the potassium saturation percentage of the soil (Sorteberg 1956, Hoffmann 1962), appears in the material of the present study only in the case of clover $\left(\mathrm{r}=-0.385^{* *}\right)$. The studies of KERÄNEN and TAINIO (1968) show that potassium fertilizing reduces the magnesium content of clover more markedly than that of timothy. Although the potassium saturation percentage in the potato fields included in the present investigation is appreciably higher $(3.3 \%)$ than that in leys $(1.8 \%)$, its influence on the magnesium content of potato leaves has no statistical significance $(\mathrm{r}=-0.070)$. The antagonism between the potassium and the magnesium did not under these conditions seem to appear as a competition for the binding sites of the cations in the plant roots. Schachtschabel (1956) as well 
as Welte and Werner (1963), have observed such competition to take place in quite exceptional instances. According to the correlations of multiple determination, in the present material, the degree of explanation of the variations in the magnesium content of plants did not rise to a statistically significant extent when the potassium saturation percentage was taken into account.

\section{S u m m a r $y$}

The sample material was collected from cultivated fields without selection based on the magnesium deficiency symptoms observed in the plants. The material consists of 115 samples of the undermost leaves from potato plants, 72 clover and 89 timothy samples, together with corresponding soil samples from the top soil of the fields.

The dependence of the magnesium content of the potato leaves, clover and timothy yields on the magnesium content of the soil and its saturation percentage, as well as on the ratio between the exchangeable potassium and magnesium on the equivalent basis, were tested by means of linear regression and correlation analyses.

The results obtained show that a highly significant positive correlation prevails between the magnesium saturation percentage of the soil and the magnesium content of potato leaves and timothy. Its effect on the magnesium content of clover could not be determined in the present study.

As the amount of exchangeable potassium present in the soil increased in relation to the magnesium, the magnesium content of the studied plants significantly decreased.

The material collected for the present investigation revealed that in the case of potato leaves, $51 \%$, and clover and timothy, $34 \%$, of the total variations in the magnesium content depended on the magnesium saturation percentage and on the ratio $\mathrm{K} / \mathrm{Mg}$ in the soil. A rise in the potassium saturation percentage significantly reduced the magnesium content of the clover alone, and taking this into account did not significantly raise the explanation percentage of the total variations in the magnesium content of any of the plants.

A c know ledgements: This paper, which represents part of a research project carried out in the Department of Agricultural Chemistry, University of Helsinki, was made possible by grants awarded by the August Johannes and Aino Tiura Agricultural Research Foundation and the Fund for Advanced Training of Agricultural Graduates. I wish to acknowledge this financial assistance with sincere gratitude.

\section{REFERENCES}

Heinonen, H. 1964. Wirkung von Niederschlag und Temperatur auf den Mineralstoffgehalt des Timotheeheus. Selostus: Sademäärän ja lämpötilan vaikutus timoteiheinän kasvinravinnepitoisuuksiin. Ann. Agric. Fenn. 3: 55-67.

Hoffmann, W. E. 1962. Der Einfluss einiger Bodeneigenschaften auf die Magnesiumversorgung der Kartoffel. Landwirtsch. Forsch. 15: 34-41.

Holmes, M. R. J. 1962. The magnesium requirements of arable crops. J. Sci. Food Agric. 13: 553-556. Hooper, L. J. 1967. The uptake of magnesium by herbage and its relationship with soil analysis data. Min. Agric. Fish. Food Tecn. Bull. 14: 160-173. 
Itallie, TH. B. van 1937. Magnesiummangel und Ionenverhältnisse in Getreidepflanzen. Bodenk. Pflanzenern. 5: 303-334.

Jokinen, R. 1969. Influence of clover content of mixed ley on magnesium and potassium in red clover and timothy. Selostus: Eri-ikäisten nurmien apilapitoisuuden vaikutuksesta apilan ja timotein magnesium- ja kaliumpitoisuuteen ja kationien suhteisiin. J. Sci. Agric. Soc. Finland 41: 3-11.

KAILA, A. \& RYTI, R. 1968. Calcium, magnesium and potassium in clay, silt and fine sand fractions of some Finnish soils. Selostus: Saves-, hiesu- ja hietafraktioiden kalsiumin, magnesiumin ja kaliumin pitoisuudesta. Ibid. 40: 1-13.

KerÄnen, T. \& TAINio, A. 1968. Hiesu- ja savimaiden kalilannoitustarpeesta. Zusammenfassung: Úber den Kalidüngungsbedarf von Lehm- und Tonböden. Ann. Agric. Fenn. 7: 161-174.

LAKAnen, E. 1969. Mineral composition of Finnish timothy. Selostus: Suomalaisen timotein kivennäisainekoostumus. Ibid. 8: 20-29.

Lengauer, E. \& Schilling, H. 1964. Verfahren zur Ermittlung von Zusammenhängen zwischen Boden und Wiesenfutter. Die Bodenkultur 15: 241-253.

Rerth, J. W. S. 1963. The magnesium contents of soils and crops. J. Sci. Food Agric. 14: 417-426.

SAlmon, R. C. 1964. Cation-activity ratios in equilibrium soil solutions and availability of magnesium. Soil Sci. 98: 213-221.

Salonen, M. \& HrvolA, S-L. 1963. Typpilannoituksen vaikutus puna-apilan ja nurminadan sadon määrän ja laatuun. Summary: The effect of nitrogen fertilization on the yield and quality of the crop of red clover and meadow fescue. Ann. Agric. Fenn. 2: 136-152.

Sснасн тschabel, P. 1956. Das Magnesiumversorgungsgrad nordwestdeutscher Böden und seine Beziehungen zum Auftreten von Mangelsymptomen an Kartoffeln. Z. Pflanzenern. Düng. Bodenk. 67: $9-24$.

SEmB, G. 1964. Studies on some magnesium aspects in Norwegian soils. 8th Int. Congr. Soil Sci. Bucarest 4: $347-355$.

Sorteberg, A. 1956. Magnesiumgjödsling. Nord. Jordbr. forskn. 38: 214-218.

Welte, E. \& Werner, W. 1963. Potassium-magnesium antagonism in soils and crops. J. Sci. Food Agric. 14: $180-186$.

\title{
SELOSTUS
}

\section{MAAN MAGNESIUMTILA JA VILJELYKASVIEN MAGNESIUMIN PITOISUUS}

\author{
RAILI Jokinen
}

\author{
Helsingin Yliopiston maanviljelyskemian laitos, Viikki \\ Maatalouden tutkimuskeskus, maanviljelyskemian ja -fysiikan laitos, Tikkurila
}

Korkeaprosenttisten lannoitteiden yleistyminen pakottaa kiinnittämään huomiota kasvien magnesiumin saantiin sitäkin suuremmalla syyllä kun magnesium on tärkeä myös eläimille.

Kasvien magnesiumin pitoisuuden riippuvuutta eräistä maan ominaisuuksista tutkittiin vuosina 1966 ja 1967 kootussa näyteaineistossa (115 perunan alalehtinäytettä, 90 nurmelta saadut 72 apila- ja 89 timoteinäytettä sekä kultakin paikalta maanäyte; taulukko 1 ja 2). Näytteiden oton tapahtuessa ei kasveissa voitu nähdä magnesiumin puutteeseen viittaavia oireita.

Kasveille käyttökelpoisen magnesiumin määrän maassa (magnesiumin kyllästysaste \% tai vaihtuva magnesium mg/100 g maata) lisääntyessä kohosi perunan lehtien ja timotein magnesiumin pitoisuus tilastollisesti merkitsevästi (piirros 1). Apilassa sen vaikutus ilmeni selvemmin sadon määrällisenä nousuna kuin magnesiumin pitoisuuden muutoksena.

Maan kaliumin kyllästysasteen lisääntyessä aleni vain apilan magnesiumin pitoisuus merkitsevästi.

Vaihtuvan kaliumin määrän magnesiumiin verrattuna noustessa maassa aleni tutkittujen kasvien ja kasvinosien magnesiumin pitoisuus erittäin merkitsevästi (piirros 2). Vaikka tämän aineiston perusteella voitiin selittää vain $51 \%$ perunan alalehtien ja $34 \%$ sekä timotein että apilan magnesiumin pitoisuudessa ilmenevästä kokonaisvaihtelusta riippuvaksi maan magnesiumin kyllästysasteesta ja suhteesta $\mathrm{K} / \mathrm{Mg}$, lienee näillä kahdella ominaisuudella merkitystä tarkasteltaessa maan magnesiumtilaa kasvien kannalta. 